\title{
Modern Monitoring Instrument to Support Fishing Vessel Operation and Maintenance: A Review
}

\author{
M. Zaki Latif Abrori ${ }^{\text {a, }}$, Sigit D.P. Sidhi ${ }^{\text {a }}$, Djoko Prasetyo ${ }^{\text {a }}$ \\ ${ }^{a}$ Fishery Mechanization, Politeknik Kelautan \& Perikanan Sorong, Sorong, 98411, Indonesia \\ Corresponding author: *m.zaki@polikpsorong.ac.id
}

\begin{abstract}
Determining the maintenance strategy for fishing vessels propulsion engines can use engine operational monitoring data. This data is used to prepare the implementation time, spare parts, labor, and costs. Unfortunately, many fishing vessels do not have this data. Currently, electronic devices are available for monitoring machine operations. This device is cheap, easy to use, takes responsibility for various physical quantity parameters, displays it on LCD, stores it digitally, and transmits data wirelessly. This paper aims to review the application of engine operational monitoring tools to apply to fishing vessel propulsion engines. The material used is scientific articles consisting of journals and proceedings indexed by online databases. Several keywords are used to obtain scientific articles that are suitable for the study. The method used is a literature review that is systematically reviewed by applying inclusion and exclusion. The results obtained in this article are the parameters for monitoring propulsion engines, namely temperature, pressure, rotational speed, and hours the engine runs. The monitoring device requires sensors to detect physical parameters, a microcontroller to process data, an LCD to display monitoring results, and memory to store data to obtain this data. The device supports wireless communication via Bluetooth or WiFi radio signal. Fishing vessels are operating in offshore areas that are not covered by internet networks as IoT communication transmissions. Further research on how to transmit operational engine data from offshore to onshore without an internet signal so that data can be accessed using the internet network.
\end{abstract}

Keywords - Monitoring devices; maintenance tools; propulsion engines; fishing vessels.

Manuscript received 28 Apr. 2021; revised 21 May 2021; accepted 26 Jul. 2021. Date of publication 31 Dec. 2021. IJASEIT is licensed under a Creative Commons Attribution-Share Alike 4.0 International License.

\section{INTRODUCTION}

Fishery activities in the north sea of Java Island are dominated by capture fisheries, which is $10.31 \%$ of the total number of fishermen all over Indonesia [1]. Those fishery activities use various fishing vessels, ranging from a fishing vessel without an engine to a fishing vessel equipped with an engine. Capture fisheries in Indonesia are dominated by traditional fishermen who use wooden fishing vessels [2], [3]. The fishing vessel can operate in a fishing ground that is relatively far from the home base. Generally, the time required for fishing vessels with a weight of 10-30GT to catch fish can reach up to 6-20 days [4], [5], while fishing vessels with purse seine fishing gear weighing up to 120GT can sail for up to 60 days [6].

Nevertheless, the machinery conditions of those traditional fishing vessels are relatively complex. It starts from the propulsion engines to the engine crew as an engine operator. An engine crew of a fishing vessel as an engine operator must have competence in fishing vessel machinery proofed by the possession of an ATKAPIN seafarer expertise certificate. However, in actual conditions, many engine crews do not have this certificate. Skills as an engine operator are limited to operate and simple maintenance and obtained through experience. This condition causes engines lifetime is not as expected.

Most of the engines that they use as vessel propulsion are not for marine usage. However, they use modified used truck engines. It caused the price of a truck engine is considered cheaper than a marine engine. Moreover, spare parts are available. The worse condition is some engines whose control instruments do not work and do not repair yet, so they cannot be used. Some of these controls include controls for engine coolant water temperature, lubricant temperature, hour meter, and others control.

When the engine is running, one of the engines watchkeeping activities is journaling the engine condition. Such as engine rotational speed, working temperature, pressure, and engine operating hours. However, under the nonfunctional instrument condition, engine running condition parameters cannot journal correctly. Parameter recording is 
only based on estimation by noticing to audio-visual and vibration. The temperature value of engine cooling water and lubricant is obtained by sensing the cooler surface with a hand. Those journaling activities are inaccurate and difficult to use as a guide for monitoring engine conditions for maintenance and repair actions.

In the absence of correct engine data conditions, the preference maintenance action is corrective maintenance (CM). Moreover, if all engine components were maintained, it would be expensive [7]. CM is only better for the low-risk parts.

Generally, ship owners implement two maintenance strategies to get optimal engine conditions. The first is corrective maintenance. This maintenance strategy can be called repair maintenance and chosen when the engine is failing to operate [8]. The second is preventive maintenance and is divided into two, namely time-based maintenance (TBM) and condition-based maintenance (CBM) [9], [10]. TBM is carried out regularly, planned at intervals of maintenance conducted before. CBM is an engine maintenance approach that emphasizes the combination of reliability models based on engine performance data collected from the engine operating conditions. CBM is also a maintenance action that utilizes real-time data and information on engine operating conditions and provides recommendations for maintenance actions based on these conditions [11]. It aims to minimize unnecessary maintenance actions as the engine is still in a decent operating condition and prevents failure on the applied preventive maintenance components due to the earlier failure time.

CBM is a part of preventive maintenance, which is also called predictive maintenance. It has been widely used by industries in various disciplines such as electricity, manufacturing, shipping, nuclear, and others. CBM is a modern maintenance strategy and a popular maintenance technique [12]-[15]. The principle of CBM action is to minimize engine maintenance costs by avoiding maintenance actions on components that are still run properly to increase engine availability [16], [17].

Components that are decent for operation and almost failure will show signs, symptoms, and indications indicated by the engine operating condition parameters [18], [19]. This engine condition parameter is obtained by inspecting or monitoring the engine [20], [21]. One of the successful implementations of the CBM strategy depends on a satisfactory inspection or monitoring system and produces accurate operational condition data of the engine.

Recently, many engines have used sensors and microcontrollers for inspection/monitoring and collecting data to implement CBM strategies. Awang [22] applied CBM to a two-stroke vessel propulsion engine using ultrasound signals. His paper stated that ultrasound signals could be applied to identify excess friction earlier. Meanwhile, Murty [23] uses vibration and temperature sensors for monitoring compressor health. The sensor senses abnormalities in misalignment, non-linearity, vibration, and temperature in the compressor which are recorded in real-time. Angius [24] for the CBM program using several sensors connected in the network to collect health condition data on critical components.
This paper describes the application of an open-source microcontroller and sensor device for recording and monitoring a real-time engine operational condition used as data on CBM action of fishing vessel engines. The device was chosen because relatively low-cost, an open-source service that makes it easy to modify and is relatively accurate and reliable.

\section{MATERIALS AND METHOD}

This article was compiled using the literature review method from several scientific articles about monitoring devices that use open source to monitor engine operations in real-time. The stages of the research method are carried out following Fig. 1.

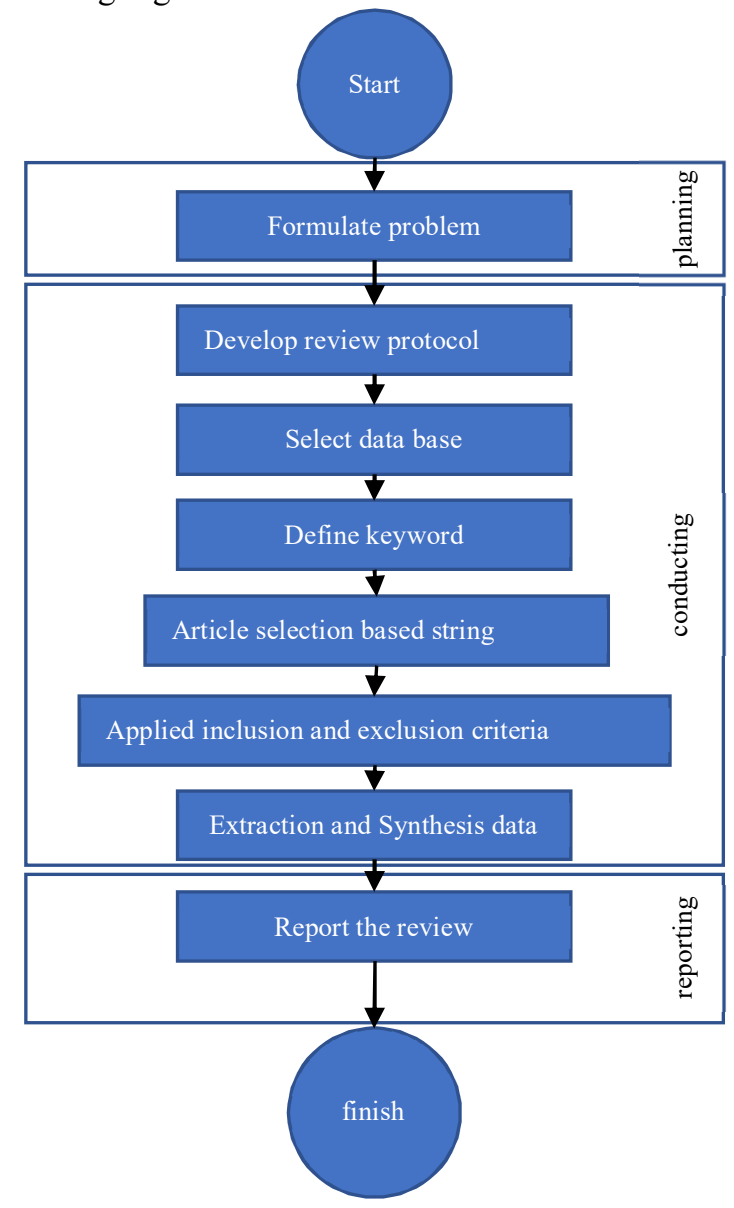

Fig. 1 Research method flow chart [25]

In this study, literature review carried out in several stages as follows Fig. 1: section A. preparation which includes 1) determining the topic of the problem to be discussed with several questions, 2) making questions; section B. conducting a review which includes 1) determining the protocol to be used, 2) selecting a digital database, selected based string keyword article, 3) selecting articles by applying inclusion and exclusion, 4) data extraction; and section C. report the results of the review.

\section{A. Planning}

Determining the topic: In the preparation stage, the thing to do was to choose the problem to be studied i.e., the operational monitoring equipment for the vessel engine propulsion. Determining questions: questions were conducted 
to retrieve, identify, and select scientific articles discussing modern devices used to monitor engine operations. The questions were divided into two groups, as shown in Table 1 i.e general questions (GQ) and specific questions (SQ). GQ aims to help develop research, and SQ aims to identify engine monitoring tools to support CBM.

TABLE I

RESEARCH QUESTION

\begin{tabular}{ll}
\hline RQ & \multicolumn{1}{c}{ Question } \\
\hline General question \\
GQ $\quad$ How engine monitoring supports CBM \\
Specific question \\
SQ1 $\quad \begin{array}{l}\text { What ability is needed to obtain operational data for } \\
\text { fishing vessel propulsion engines? }\end{array}$ \\
SQ2 $\quad \begin{array}{l}\text { What parts can be used as a monitoring device for } \\
\text { fishing vessel propulsion engines? }\end{array}$ \\
SQ3 $\quad \begin{array}{l}\text { How is the implementation of monitoring equipment for } \\
\text { propulsion engines on fishing vessels? }\end{array}$ \\
\hline
\end{tabular}

\section{B. Conducting}

Developing a protocol: in carrying out research using a predetermined protocol so that research does not widen and become biased. Protocols used to formulate questions, strategies used to search for data, selection with inclusion and exclusion criteria, data synthesis. The stage of conducting the review in Fig. 1. The first step was articles search in the Google Scholar online database using the following keywords and strings.

\section{“(device OR tools) AND (monitoring OR recording) AND (operational OR maintenance) AND (machinery)."}

Articles obtained from search results were read in the title, abstract, introduction, and conclusion sections. To use articles properly, inclusion criteria were applied to determine the articles to be used. The inclusion criteria used were 1) articles can be in the form of journals or proceedings; 2) the articles were written in English, and some articles can be in Indonesian (the object of fishing vessels in Indonesia); 3) Articles written in 2017-2021; 4) Studies that discuss the concept of engine monitoring parameter using microcontrollers; 5) Studies that discuss and answer GQ and SQ (Table 1).

The next stage applied exclusion criteria to filter and eliminate irrelevant articles. The exclusion criteria used were 1) Studies that do not discuss the concept of engine operational monitoring parameters using micro-controllers, 2) Studies that do not discuss and answer GQ and SQ; 3) Book articles and dissertation or thesis reports; 4) Articles from searches that cannot be downloaded from the database.

After the exclusion stage, all selected articles were read and studied to find out which parts were discussed to answer the GQ and SQ questions.

\section{Reporting}

The report was made based on a general perspective to answer research questions that have been determined previously. The report was written by using Microsoft Office tools. The sentences that match the discussion were then quoted and entered as a library. Mendeley's citation manager was used to organize and filter to create well-organized bibliographic references. This process was carried out by three people who know machine parameter monitoring and have a mechanical engineering background in different scientific fields.

\section{RESULTS AND DISCUSSION}

\section{A. GQ (Engine Monitoring Supports CBM)}

Engine monitoring onboard is a periodic engine inspection that aims to maintain the engine running in good condition so that the instrumentation can run properly. In the implementation, engine monitoring is conducted by the engine crew checking the engine's operational performance conditions and structured documenting in the engine logbook. The result recorded in the logbook is the value of the engine parameters in real-time at any given time interval [26]. When the engine runs in an abnormal condition, that condition is also recorded in the engine logbook.

The criteria for monitoring devices that can be used to support the implementation of CBM, i.e., can collect data on engine parameter values, classify data, and detect disturbances that occur in engines. In 4.0, temperature monitoring allows monitoring in real-time [27], [28]. The monitoring results can be saved or recorded in digital data form, i.e., log data used for various purposes. One of them is for CBM action analysis.

Obtaining engine operational $\log$ data as an analysis material for implementing the CBM strategy involves the sensor device designated to inspect the engine [29]. Inspecting engine operating parameters routinely by humans requires a considerable cost. Therefore to reduce the cost, electronic sensors can be used [30]. Engine monitoring devices with electronic sensors can be applied because they have a small dimension size, vibration resistance, no moving parts, lower prices, and ease to get [31], [32].

Generally, fishing vessels use diesel engines as their propulsion. Diesel engines are chosen because of their high efficiency, power, and reliability compared to other compatible power sources [33]. To keep the diesel engine in good condition, it is necessary to monitor the operating conditions of the machine parameters. These parameters are lubricant temperature and lubricant pressure [34], engine coolant temperature [35], rotational speed [36], and battery charger voltage [37]. The other essential data is the engine running hours $(\mathrm{RH})$, where $\mathrm{RH}$ functions to find out the accumulative time of how long the engine has been running. With this condition monitoring data, maintenance decisions can be made as needed. Besides that, which is no less crucial, maintenance can be conducted effectively and efficiently and contribute to the business profitability [38].

\section{B. QS1 (The abilities needed to obtain operational data of fishing vessel propulsion engines)}

Various existing monitoring devices, although of different types and technologies, still use the same principles. In principle, the monitoring device consists of three stages, i.e., sensing, processing, and reporting [39] Fig. 2. The required criteria ability as a monitoring device on fishing vessels are shown in Table 2. 


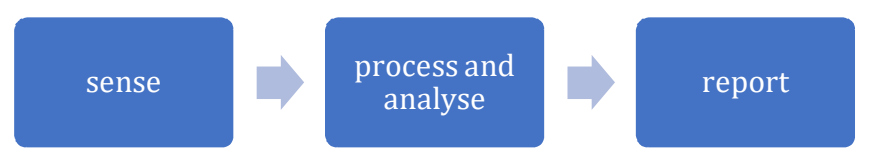

Fig. 2 Monitoring Principle [39]

TABLE II

MONITORING DeVICE ABILITY

\begin{tabular}{ll}
\hline Required Function & Detail \\
\hline $\begin{array}{l}\text { Reading engine } \\
\text { running parameters }\end{array}$ & $\begin{array}{l}\text { Convert mechanical data such as } \\
\text { temperature, pressure, voltage, engine } \\
\text { speed, operational time, and running } \\
\text { hours on vessel propulsion engines } \\
\text { into analog data. }\end{array}$ \\
Processing digital & $\begin{array}{l}\text { Process digital data to produce output } \\
\text { that can drive the actuator, save it in } \\
\text { memory and show it on display. } \\
\text { data }\end{array}$ \\
Collect and save data from engine \\
operational data processing held in \\
memory on parameters measured by \\
time in real-time. \\
Report the results of parameter \\
monitoring through the display so that \\
the engine operator can understand it. \\
Processed data (collected, grouped) \\
can be sent to other devices for \\
analysis purposes. It can conduct using \\
a cable or wireless.
\end{tabular}

C. QS2. (The parts used as a monitoring device for fishing vessel propulsion engines)

The engine monitoring device generally consists of several parts Fig. 3. At the stage of sensing the parameters of a physical phenomenon in the engine is the sensor duty [40], [41]. This monitoring device requires several sensors to detect some physical changes. Some of the physical data obtained by the sensor are raw data that must be processed and analyzed further by the processor, i.e., a microcontroller [42], [43]. However, to display data processed by the processor using the LCD display [44], while Ruobing [45] used the display on a computer or smartphone. Reporting using this device can make it easier for users, i.e., vessel engine operators, maintenance technicians, and vessel owners.

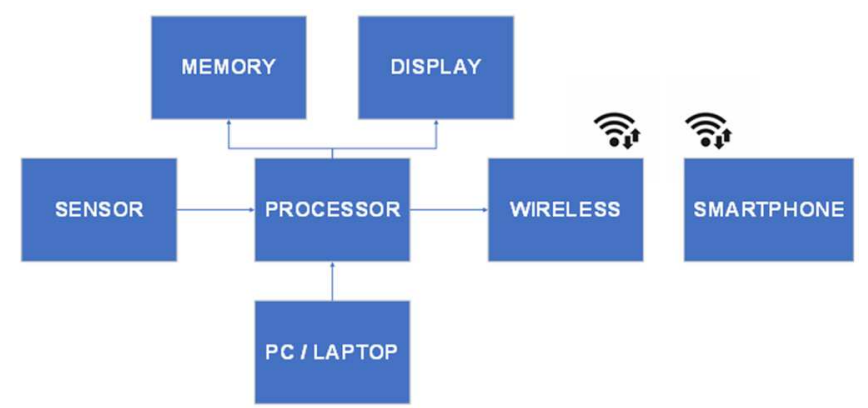

Fig. 3 General Design of Engine Monitoring Device That Uses A Wireless Connection [46]

This device is programmed to receive various input signals from several sensors placed at several points, then read engine parameters, process, and display. The results of the data processor can be used directly by the control system.
Moreover, it also utilizes as a trigger for engine control actuators such as relays, solenoids, and alarm warning signs.

Through a display embedded in this device, engine operators would know engine performance easier. Start from the cooling water temperature, lubricant temperature, lubricant pressure, battery voltage conditions, and how long the engine has been running. It can also help operators take the right steps in carrying out operations and engine maintenance well.

The processed data by the processor is saved temporarily by the device. However, to save lots of data for a longer time, the data is saved periodically in the embedded memory [47]. Embedding a memory to the device can help technicians or the maintenance team to read operational history and engine failure when the vessel engine is running. This data is useable as a material for making engine maintenance planning decisions.

A monitoring device can use an open-source processor to process data in the physical magnitude form and report it through the monitor. When the device detects abnormal conditions on the engine, this device can give a warning signal [48] so that the operator or vessel crew can provide corrective action.

1) Sensor: Vessel propulsion engine running performance is affected by several physical parameters, including engine coolant temperature, lubricant temperature, lubricant pressure, engine rotational speed, and engine running hour meter. It causes monitoring devices requiring multiple detection sensors [49]. The essential things in diesel engine operation, such as engine cooling, lubricant pressure, structural deficiencies, and breakdown of the indicator, can be monitored using sensors [50]. Some of the sensors used to detect the engine's physical parameters are shown in Table 3 [51]-[54]. The references that discussed the sensor to determine the physics parameter are shown in Table 4.

TABLE III

REQUIRED SENSOR TO DETECT ENGINE RUNNING

\begin{tabular}{ll}
\hline Physical Parameters & \multicolumn{1}{c}{ Part which Monitored } \\
\hline Temperature & $\begin{array}{l}\text { Cooling water temperature at the inlet } \\
\text { and outlet of the heat exchanger and } \\
\text { the lubricant in the oil reservoir } \\
\text { Lubricant circulation pressure in the } \\
\text { engine lubrication system }\end{array}$ \\
Pressure & $\begin{array}{l}\text { Engine rotational speed } \\
\text { Length of engine running time }\end{array}$ \\
Engine speed &
\end{tabular}

A diesel engine is an internal combustion engine, which converts chemical energy obtained from liquid fuel and burns it in the combustion chamber to become heat energy [55]. The heat energy is used to push the piston from TDC to BDC to generate mechanical energy that transfers to the propeller to drive the vessel. Running a diesel engine will generate heat, where the maintained heat when the engine running is between $75-80^{\circ} \mathrm{C}$ [56], and excessive heat will cause the engine to deteriorate fatal damage. In diesel engines, the monitored temperatures are cooling water temperature and lubricant temperature [57]. Determine the cooling water temperature value, a temperature sensor put on the liner cylinder's water pipe [58], [59]. Meanwhile, to find out the lubricant temperature value, a sensor was placed on the engine crankcase as a lubricant reservoir for the engine. 
TABLE IV

PARAMETERS FOR MACHINE MONITORING

\begin{tabular}{|c|c|c|}
\hline Reference & $\begin{array}{l}\text { On The } \\
\text { Display }\end{array}$ & The Used Data for Monitoring \\
\hline$[57]$ & $\begin{array}{l}\text { Lubrication } \\
\text { System } \\
\text { Temperature }\end{array}$ & $\begin{array}{l}\text { Pressure and temperature lubrication to } \\
\text { detect a disturbance }\end{array}$ \\
\hline$[58]$ & $\begin{array}{l}\text { Water } \\
\text { Temperature }\end{array}$ & Engine diesel coolant temperature \\
\hline [59] & $\begin{array}{l}\text { Cylinder Liner } \\
\text { Temperature }\end{array}$ & Energy efficiency \\
\hline$[60]$ & $\begin{array}{l}\text { Fuel } \\
\text { Temperature }\end{array}$ & $\begin{array}{l}\text { Remote monitoring thermal preparation } \\
\text { process an engine }\end{array}$ \\
\hline$[61]$ & $\begin{array}{l}\text { Vehicle } \\
\text { Temperature }\end{array}$ & $\begin{array}{l}\text { Engine temperature when vehicle } \\
\text { running }\end{array}$ \\
\hline [63] & Oil Pressure & Pipe leakage detection \\
\hline [64] & $\begin{array}{l}\text { Hydrogen } \\
\text { Pressure }\end{array}$ & $\begin{array}{l}\text { Hydrogen flow control in the simple } \\
\text { furnace }\end{array}$ \\
\hline$[65]$ & $\begin{array}{l}\text { Engine } \\
\text { Rotational } \\
\text { Speed }\end{array}$ & $\begin{array}{l}\text { Rotational speed to performance and } \\
\text { emission comparison }\end{array}$ \\
\hline$[66]$ & $\begin{array}{l}\text { Engine } \\
\text { Rotational } \\
\text { Speed }\end{array}$ & $\begin{array}{l}\text { Rotational speed to performance and } \\
\text { emission comparison }\end{array}$ \\
\hline [67] & $\begin{array}{l}\text { Rotational } \\
\text { Speed }\end{array}$ & $\begin{array}{l}\text { Rotational speed to measure wind } \\
\text { power }\end{array}$ \\
\hline$[68]$ & $\begin{array}{l}\text { Rotational } \\
\text { Speed }\end{array}$ & $\begin{array}{l}\text { Rotational speed of diesel engine with } \\
\text { alternative fuel }\end{array}$ \\
\hline [69] & Running Hour & Running hour to analysis reliability \\
\hline$[70]$ & Running Hour & $\begin{array}{l}\text { Engine conditions related to the } \\
\text { component lifetime }\end{array}$ \\
\hline$[71]$ & Running Hour & $\begin{array}{l}\text { Determine the wear of rotating engines } \\
\text { by monitoring running hours }\end{array}$ \\
\hline
\end{tabular}

Manufacturers produce several sensors to measure temperature, i.e., LM35, DHT11, DHT22, and DS18B20. Gritsuk [60] used a DS18B20 thermocouple sensor to measure temperature coolant in the diesel engine. DS18b20 is a relatively accurate temperature sensor with an accuracy of 9 to 12 bits, in a temperature range of $-55^{\circ} \mathrm{C}$ to $125^{\circ} \mathrm{C}$ [61]. This sensor communicates to the microprocessor using 1 data cable and one ground cable, where the required voltage source is obtained from the data cable. This sensor can work 64bit to connect one communication cable with several different functions [62].

When a diesel engine is running, many component mechanisms are connected and rubbed each other. If the component that rubs each other did not well lubricated, it would impact wear. Many diesel engines currently apply a pressure lubrication system, where the gear pump sucks lubricant from the crankcase and discharges it into the gaps of friction objects. Monitoring lubricant pressure in diesel engines is significant because it determines the condition of the lubricant circulation. Knowing the lubricant condition in real-time makes it possible to prioritize the correct maintenance schedule accurately.

A good lubricant circulation of a diesel engine is indicated by lubricant pressure value following that determined by the manufacturer. In contrast, lubricants with pressures below manufacturer standards show a disturbance in the lubricant circulation. The trouble of lubricant circulation must be immediately taken into action to prevent further damage such as jamming the piston on the cylinder liner, wearing valve, bearing, and the shaft on the engine.

Several sensors can be used to measure pressure. Okpare [63] used the HK1100c sensor to monitor leaks of pipelines that carry oil. Darjat [64] also used HK1100c to take control of hydrogen and oxygen pressure in his paper. The HK1100c pressure sensor can read pressure ranging from 0-1.2 $\mathrm{MPa}$ with an accuracy of $\pm 1.0 \%$ FSO. This sensor works using a $5 \mathrm{~V}$ DC voltage. The diesel engine used in fishing vessels is a high-speed diesel engine. Stationary rotational speed reaches $800 \mathrm{rpm}$, and when the vessel sails, it can reach $1200 \mathrm{rpm}$. Engine speed is essential to monitor because the number of engine revolutions considerably influences a diesel engine's performance. The number of engine revolutions will affect engine performance [65], while engine performance is affected by water temperature and lubricant temperature [66].

To monitor the amount of engine rotational speed using a rotation sensor. Some sensor devices that can detect engine rotational speed include IR sensors with the optocoupler or proximity principle and inductive sensors with the proximity principle [67]. Gabina [68] measured rotational speed in a diesel engine using an inductive proximity sensor. This device can provide contactless measure rotational speed by utilizing the eddy current field principle.

Occurrence time is always included in monitoring to know the occurrence time accurately. It can help determine the timing of occurrence and calculate how long the engine has been running [69]. To determine the occurrence time and how long the engine has been running, a running hour $(\mathrm{RH})$ meter can be used. RH meter works by recording every running hour, and the value will continue to increase over time. If the engine did not run, $\mathrm{RH}$ would stop recording the running time. $\mathrm{RH}$ is beneficial for knowing engine conditions related to the component lifetime, which is essential in calculating the reliability value [70]. RH can also help analyze engine failures, such as Poppe [71], in his research to determine the wear of rotating machines by monitoring running hours.

The device in charge of keeping track of time is a "realtime clock" commonly known as the RTC. RTC is an electronic clock that calculates the time from seconds to years and saves it in digital data on an added memory device [72]. RTC is used by Iskandar [73] as a timer for data collection in a photovoltaic photosystem application. A list of sensors that can be used as a monitoring device for vessel propulsion engines is shown in Table 5.

TABLE V

List of The SENSOR TO MONITOR DiESEl ENGINE

\begin{tabular}{|c|c|c|c|c|}
\hline $\begin{array}{l}\begin{array}{l}\text { Type of } \\
\text { sensor }\end{array} \\
\end{array}$ & $\begin{array}{l}\text { Magnitude } \\
\text { Detected }\end{array}$ & $\begin{array}{l}\text { Advantag } \\
\text { es }\end{array}$ & Disadvantages & $\begin{array}{l}\text { Applicatio } \\
\text { n Usage }\end{array}$ \\
\hline thermal & temperature & $\begin{array}{l}\text { Stable, } \\
\text { good } \\
\text { accuracy, } \\
\text { wide } \\
\text { measuring } \\
\text { range. }\end{array}$ & $\begin{array}{l}\text { It is challenging to } \\
\text { detect fast and } \\
\text { random changes }\end{array}$ & $\begin{array}{l}\text { Detecting } \\
\text { the } \\
\text { temperature } \\
\text { of the } \\
\text { coolant and } \\
\text { engine oil }\end{array}$ \\
\hline $\begin{array}{l}\text { Inductive } \\
\text { electromag } \\
\text { netic }\end{array}$ & pressure & $\begin{array}{l}\text { Compact, } \\
\text { fast } \\
\text { response, } \\
\text { good } \\
\text { sensitivity. }\end{array}$ & $\begin{array}{l}\text { Sensitive to } \\
\text { magnetic fields } \\
\text { and temperature }\end{array}$ & $\begin{array}{l}\text { Oil } \\
\text { pressure, } \\
\text { gas pressure }\end{array}$ \\
\hline $\begin{array}{l}\text { Inductive } \\
\text { proximity }\end{array}$ & $\begin{array}{l}\text { Engine } \\
\text { rotational } \\
\text { speed }\end{array}$ & $\begin{array}{l}\text { Compact, } \\
\text { fast } \\
\text { response, } \\
\text { good } \\
\text { sensitivity, } \\
\text { and } \\
\text { applicable. }\end{array}$ & $\begin{array}{l}\text { Sensitive to } \\
\text { magnetic fields } \\
\text { and requires a } \\
\text { short distance for } \\
\text { good accuracy. }\end{array}$ & $\begin{array}{l}\text { Measuring } \\
\text { engine } \\
\text { rotational } \\
\text { speed }\end{array}$ \\
\hline Oscillator & Time & $\begin{array}{l}\text { Accurate, } \\
\text { compact } \\
\text { form, uses } \\
\text { low power. }\end{array}$ & $\begin{array}{l}\text { Sensitive to } \\
\text { temperature. }\end{array}$ & $\begin{array}{l}\text { Measuring } \\
\text { time in real- } \\
\text { time }\end{array}$ \\
\hline
\end{tabular}


2) Processor: The data obtained by the sensor to detect physical quantities cannot be read directly by humans, the process still requires a processor. Several processors can be used to process data, including Arduino, Raspberry Pi, Intel Edison, Mediatek Linkit One, NVIDIA Jetson Nano [74]. Arduino and Raspberry $\mathrm{Pi}$ are the most widely used processors because of their simplicity and easy operation [26], [75] show in Table 6. Arduino is a processor that uses an open-source platform so that the hardware or software can be modified as needed to make it easier to use [76]. Temperature sensors with code DS18B20 can use Arduino as the processor [77], [78]. Likewise, in his article Zariatin [79] measured water pressure using the HK1100c sensor with an Arduino board processor for measuring pressure. Similarly, to get the rotational speed and time of Arduino, Putu [80] used Arduino as the processor. The Arduino board is hardware, where to run commands requires commands using the $\mathrm{C}++$ language. Creating commands, modifying and uploading commands in $\mathrm{C}++$ using the open-source Arduino IDE software [81].

TABLE VI

ARDUINO PROCESSOR DIFFERENCES WITH RASPBERRY PI

\begin{tabular}{|c|c|c|}
\hline Criteria & Arduino & Raspberry Pi \\
\hline General & Microcontroller & Microcomputer \\
\hline Processor & $\begin{array}{l}\text { AVR 8-bit, simple, } \\
\text { aplicable, } \\
\text { ATMega328P@16 } \\
\text { MHz }\end{array}$ & $\begin{array}{l}\text { ARM 64-bit, } \\
\text { complex, BCM2837 } \\
\text { (a) } 1.2 \mathrm{GHz}\end{array}$ \\
\hline $\begin{array}{l}\text { Program } \\
\text { running } \\
\text { (multitasking) }\end{array}$ & $\begin{array}{l}\text { At the same time, } \\
\text { only one program can } \\
\text { be run. }\end{array}$ & $\begin{array}{l}\text { At the same time, } \\
\text { several programs } \\
\text { can be run. }\end{array}$ \\
\hline Connectivity & $\begin{array}{l}\text { There is no built-in } \\
\text { wired or wireless } \\
\text { module but can add } \\
\text { an add-on module to } \\
\text { provide that } \\
\text { capability. }\end{array}$ & $\begin{array}{l}\text { It has built-in WiFi, } \\
\text { Bluetooth, and } \\
\text { ethernet } \\
\text { connectivity. }\end{array}$ \\
\hline $\begin{array}{l}\text { Operating } \\
\text { system }\end{array}$ & None & Raspbian \\
\hline Memory & $\begin{array}{l}\text { Arduino is equipped } \\
\text { with three types of } \\
\text { memory, namely } \\
\text { flash, SRAM, and } \\
\text { EEPROM. }\end{array}$ & $\begin{array}{l}\text { It is equipped with } \\
\text { RAM memory } \\
\text { capacity of } 1 \text { GB } \\
\text { (Raspberry Pi } 32 \mathrm{~B} / \\
\text { 3B / 3B +) }\end{array}$ \\
\hline Port & $\begin{array}{l}\text { A single USB port is } \\
\text { provided for program } \\
\text { uploading and an } \\
\text { ICSP header for } \\
\text { debugging. }\end{array}$ & $\begin{array}{l}\text { It has a USB host } \\
\text { port, HDMI, CSI, } \\
\text { DSI, audio jack, and } \\
\text { an ethernet port. }\end{array}$ \\
\hline $\begin{array}{l}\text { Programing } \\
\text { Language }\end{array}$ & $\mathrm{C}$ dan $\mathrm{C}++$ & $\begin{array}{l}\text { Phyton, } \mathrm{C}, \mathrm{C}++ \text {, } \\
\text { ruby }\end{array}$ \\
\hline
\end{tabular}

3) Display: To report data that the processor has processed can use the display. Several displays have been used for monitoring devices, i.e., LCDs, smartphones, and computers. The LCD is an electronic display that uses liquid to display visual information. A compact form makes it easy to attach to monitoring devices and easy to use with Arduino [75]. Several sizes of LCDs that are widely used to display monitoring results are $16 \times 2$ and $16 \times 4$. The development of electronics is rapid, and it is also applied to smartphones and computers. Smartphone devices are also similar to computers, having a processor, memory, and display. Smartphones can also display the results of monitoring carried out by sensors and processors [82], [83]. The advantages of smartphone monitoring can be conducted via mobile as long as it is connected to a network of engine monitoring devices.

4) Communication: The engine monitoring device can monitor the engine's operating conditions directly at the engine location, where the sensor is permanently installed on the monitored part. The results of this monitoring are displayed visually through the display. Communication between devices and engine operators can be done in several ways, i.e. conventional, portable, Wireless communication in the local area, and internet communication.

The conventional diesel engine operational monitoring device on fishing vessels is the engine manufacturer's default and permanently installed on the dashboard. This conventional device is still simple and relatively more expensive, as the communication between the sensor and the dashboard uses cables and capillary pipes, so the engine operator must record the engine's operational monitoring.

The portable type of monitoring device is compact, lightweight, and can be used on mobile. This type is widely used to monitor engine operational parameters and occurrences when the engine is running. Some authors of scientific articles, such as Krishnamoorthi [84] used portable monitoring devices to analyze diesel engines' availability, performance, and emissions. This type of device has a weakness, i.e., the sensor placement is not fixed. It can cause noise in the measurement and causing measurement errors [85].

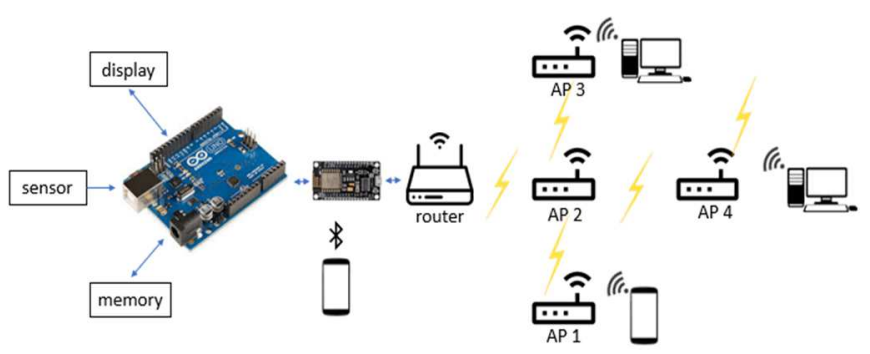

Fig. 4 Wireless engine monitoring can be accessed in a limited local area [26].

Wireless communication monitoring devices can be carried out in local areas without using the internet Fig. 4. The monitoring device with the wireless method works by collecting data. The data is processed by the processor and send to the operator's data [39]. Communication between devices and humans as technicians is wirelessly carried out by devices via Bluetooth [86]. Bluetooth exchanges information between Arduino equipment, smartphones, computers, and other devices that support Bluetooth transmission via free license short-range radio frequency communication channels [87], [88]. Other wireless communications can also use WiFi signals [89] to transmit radio signals at a frequency of $2.4 \mathrm{GHz}$ or $5 \mathrm{GHz}$ [90].

Modern monitoring devices currently widely used data communication using the internet based on micro-control [91] Fig. 5. Monitoring engine conditions using internet communication is used because it is practical. It does not need to be where the engine is located to monitor engine parameters but can be done in any area as long as the internet network covers the area. Monitoring devices with internet line communication are also used to monitor air pollution [92], 
[93]. Using the internet line requires an MCU node module device to transmit data from the microprocessor to the internet network [94]. Through the internet network, engine monitoring results in real-time can be distributed and accessed in all areas covered by the internet network

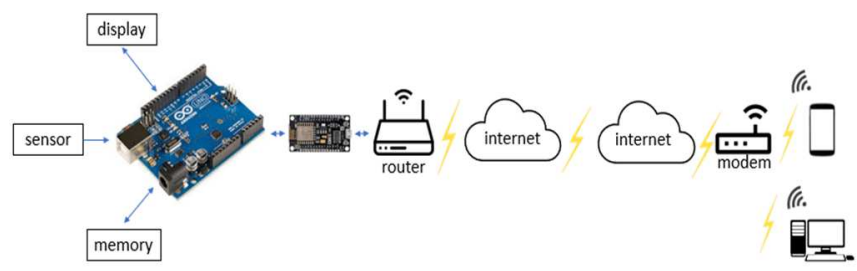

Fig. 5 Engine monitoring that can be accessed in the broader area using an internet connection [27], [95]

5) Memory: The success of condition-based maintenance measures on diesel engines is considerably influenced by data availability regarding engine parameters. To get engine parameter data in conventional monitoring, the operator must watch the engine panel and record it in the engine logbook. In modern monitoring devices, the data collected by the sensor is processed by a microprocessor, and then the data is collected and recorded on a memory card in the device. Memory cards are essential for storing large amounts of data for a long time [96]-[98]. Engine monitoring devices use a Micro SD memory card to save data on a memory card [99].

\section{QS3. (The implementation of monitoring equipment for propulsion engines on fishing vessels)}

The installed monitoring devices will be easy to implement. It is because this device works using a DC source that comes from vessel batteries. However, batteries on vessels generally have a 12-24 VDC voltage, while the voltage used by this engine monitoring device uses a voltage of 9-5 VDC. It requires a DC step down to use for the battery [100]. The voltage needed for each module, i.e., sensors, processors, displays, and memory.

The required sensor must be placed in the right position; improper sensor placement will result in fatal parameter measurement errors. For reading the engine rotational speed value, the sensor must be put in a place that can reach the part of the rotating engine shaft. Generally, the part used to measure rotational speed is the flywheel [101]. The sensor was placed a little ahead of the thermostat to get the engine coolant temperature value [102], [103]. It is because the coolant used after cooling the engine exits through this channel. The lubricant pressure sensor is placed in the lubricant channel after the lubricant filter [35]. The pressure sensor's position will detect a pressure change if a disturbance in the pump or dirt clogs the filter.

This monitoring device sold in the market is knockdown, easily assembled, and connected using a connecting cable. In the application, if much movement on the line can cause the cable connection to become loose [104] and cause errors in the parameter monitoring process. Fishing vessel movement caused by waves and engine activity allows the connection to loosen. Therefore to prevent this, all connecting cables must be connected using terminals that are screwed tightly and the processor placed in a fixed place. The LCD display is placed near the engine, on the control panel, and on the dashboard on the bridge to make engine parameters through this device read easier.
LCDs are placed near the engine to make monitoring and record actions on the logbook easier. Meanwhile, to complete engine monitoring easier, the generated data is distributed via wireless transmission to the local area network using a network topology as in Fig. 4. The physical quantity that the microcontroller has processed is emitted by the Bluetooth or WiFi module ESP8266 to be distributed by the router and accessed locally [105]. The router can be placed in the engine control room. The signal emitted by the router is then distributed evenly by the access point (AP). AP is set in several different locations, so that engine monitoring data can be accessed at the desired location using a smartphone or computer without going down to the control room or bridge.

Recorded engine operations in the engine logbook are also digitally backed up on the memory card. The digital data recorded on the memory card will help the engineer monitor engine operations while sailing. When the vessel returns to the home base to unload the caught fish, the engineer can download the memory card's monitoring data using smartphones or laptops. Engine monitoring data in digital form is more simple to process, such as tabulation, data sorting making it easier to perform computation and machine analysis for condition-based machine maintenance actions [106]. Engine monitoring data can calculate failure rates or changes in engine dynamics in the actual system. If the value deviated from the given value, it could be used as a trigger for taking condition-based preventive treatment measures [107].

\section{E. Challenges of Applying IoT in Monitoring Vessel Engines}

The growth of fishing activities in Indonesia tends to increase, especially at the industrial level, with a fleet of more than 30 GT. Fishing vessels with a size of more than 30 GT have a fishing ground of more than 12 nautical miles [108]. Monitoring devices using an Arduino microprocessor can be communicated using the internet [93], [109]. However, to support communication with the internet, the internet network must cover the area.

In Indonesia, fishing vessels operating areas more than 12 nautical miles from the coastline are mostly not covered by internet networks. Therefore, the future challenges to this device can be applied to IoT, so it requires a device that can send and receive signals with a radius of more than 12 nautical miles.

Based on an article written by Jiang [110], the communication system developed for use in the oceans is the maritime satellite and radio system. For satellite communication, the operational costs charged to the customers are relatively high because of the high investment costs. As a result, the satellite system to support engine monitoring communication via the internet is not comparable. The maritime radio system is the most popular. It is because of its ability to work in a large area of water. Very high frequency (VHF) signals operate in the range 156-162.025 $\mathrm{MHz}$ with a total bandwidth of $6.025 \mathrm{MHz}$ and channel spacing of $50 \mathrm{kHz}$ and $25 \mathrm{kHz}$ capable of supporting analog voice communications up to about $111 \mathrm{~km}$. Multiple VHF channels are used to develop a VHF data link (VDL) to provide data communication for an automatic identification system (AIS) at a maximum speed of $9.6 \mathrm{kbps}$.

A modulator is needed to use a VHF signal to superimpose the information data signal with a carrier frequency signal to 
work in the Arduino ecosystem [111]. With this modulator, it is expected that the information signal transmitted from vessels in the ocean can be received at VHF receivers on land and then transmitted on the internet network.

\section{CONCLUSION}

Currently, technology development is developing rapidly, especially in the engineering sector. Unfortunately, many engines used on traditional fishing vessels in Indonesia still apply old technology, conventional and manual engine monitoring devices. Even many instruments to measure engine parameters do not work, so that the vessels do not have engine operational data.

Engine operational data is an essential part of an excellent successful operation and engine maintenance. It is now possible to collect engine operational data using modern equipment and is easy to obtain at an affordable price. The engine monitoring device model described in this paper is relatively attractive because it uses several open-source sensors and microprocessors, but it has not been applied to conventional engines as propulsion of fishing vessels.

With digital data in the engine real-time, this device can facilitate planning for maintenance of vessel propulsion engines, preparing spare part supplies, maintenance costs, labor, and providing time to carry out the work. With careful planning, it is expected that there will be no undone engine maintenance actions, so that engine performance maintains in good condition.

\section{ACKNOWLEDGMENT}

This research was supported by the research and community service center and was financed by Politeknik Kelautan dan Perikanan Sorong.

\section{REFERENCES}

[1] B. P. Statistics, "Statistics of marine and coastal resources 2016," Statistics Indonesia, 2017

[2] Y. Praharsi, M. A. Jami'in, G. Suhardjito, and H.-M. Wee, "The Comparison of Characteristics Profile of the Traditional Fishing Boats in Lamongan, Probolinggo, and Pasuruan, Indonesia," in International Conference on Industrial Engineering and Operations Management, 2019, pp. 2175-2185.

[3] L. Bochary et al., "Cost Comparison for the Installation of Steel Frames vs Wooden Frames on a Traditional Wooden Fishing Boat in South Sulawesi," in IOP Conference Series: Materials Science and Engineering, 2020, vol. 875, no. 1, p. 12080.

[4] M. Natsir, A. A. Widodo, W. Wudianto, and S. Agnarsson, "Technical Eficiency of Fish Aggregating Devices Associated With Tuna Fishery in Kendari Fishing Port-Indonesia," Indones. Fish. Res. J., vol. 23, no. 2, pp. 97-105, 2018.

[5] A. Basith, H. Prayitno, A. Saputra, and Z. R. Fadly, "Productivity and Profit-Sharing System Cantrang Fisheries in Eretan Kulon Indramayu District West Java Indonesia," Int. J. Eng. Sci., vol. 7, no. 12, pp. 4651, 2018 .

[6] S. Yuniarta, P. A. M. van Zwieten, R. A. Groeneveld, S. H. Wisudo, and E. C. Van Ierland, "Uncertainty in catch and effort data of smalland medium-scale tuna fisheries in Indonesia: Sources, operational causes and magnitude," Fish. Res., vol. 193, pp. 173-183, 2017.

[7] A. Consilvio, A. Di Febbraro, R. Meo, and N. Sacco, "Risk-based optimal scheduling of maintenance activities in a railway network," EURO J. Transp. Logist., vol. 8, no. 5, pp. 435-465, 2019.

[8] T. Yu, C. Zhu, Q. Chang, and J. Wang, "Imperfect corrective maintenance scheduling for energy efficient manufacturing systems through online task allocation method," J. Manuf. Syst., vol. 53, pp. 282-290, 2019.

[9] F. B.-S. Tayeb, K. Benatchba, and A.-E. Messiaid, "Game theory- based integration of scheduling with flexible and periodic maintenance planning in the permutation flowshop sequencing problem," Oper. Res., vol. 18, no. 1, pp. 221-255, 2018.

[10] K. Hamdan, M. Tavangar, and M. Asadi, "Optimal preventive maintenance for repairable weighted k-out-of-n systems," Reliab. Eng. Syst. Saf., vol. 205, p. 107267, 2021.

[11] S. Alaswad and Y. Xiang, "A review on condition-based maintenance optimization models for stochastically deteriorating system," Reliab. Eng. Syst. Saf., vol. 157, pp. 54-63, 2017.

[12] S. Sajid, A. Haleem, S. Bahl, M. Javaid, T. Goyal, and M. Mittal, "Data science applications for predictive maintenance and materials science in context to Industry 4.0," Mater. Today Proc., 2021.

[13] M. Tahan, E. Tsoutsanis, M. Muhammad, and Z. A. A. Karim, "Performance-based health monitoring, diagnostics and prognostics for condition-based maintenance of gas turbines: A review," Appl. Energy, vol. 198, pp. 122-144, 2017.

[14] X. Zhao, Z. Liang, A. Parlikad, and M. Xie, "Dynamic imperfect condition-based maintenance for systems subject to nonlinear degradation paths," Ind. Maint. Reliab. Manchester, UK 12-15 June, 2018,p. 190, 2018.

[15] H. Jin, F. Han, and Y. Sang, "An optimal maintenance strategy for multi-state deterioration systems based on a semi-Markov decision process coupled with simulation technique," Mech. Syst. Signal Process., vol. 139, p. 106570, 2020.

[16] X. Han, Z. Wang, M. Xie, Y. He, Y. Li, and W. Wang, "Remaining useful life prediction and predictive maintenance strategies for multistate manufacturing systems considering functional dependence," Reliab. Eng. Syst. Saf., vol. 210, p. 107560, 2021.

[17] I. Ejaz, M. Alvarado, N. Gautam, N. Gebraeel, and M. Lawley, "Condition-Based Maintenance for Queues With Degrading Servers," IEEE Trans. Autom. Sci. Eng., vol. 16, no. 4, pp. 1750-1762, 2019.

[18] A. H. de Andrade Melani, C. A. Murad, M. A. de Carvalho MichalsNi, A. C. Netto, G. F. M. de Souza, and S. In. Nabeta, "Updating a Hydro Power Plant Monitoring System Through Failure Modes and Symptoms Analysis," 2019.

[19] M. Fonte, L. Reis, V. Infante, and M. Freitas, "Failure analysis of cylinder head studs of a four stroke marine diesel engine," Eng. Fail. Anal., vol. 101, pp. 298-308, 2019.

[20] Y. Zhongda, "Borescope Inspection Management for Engine," IOP Conf. Ser. Earth Environ. Sci., vol. 128, p. 12013, 2018.

[21] Y. Xu et al., "An anomaly detection and dynamic energy performance evaluation method for HVAC systems based on data mining," Sustain. Energy Technol. Assessments, vol. 44, p. 101092, 2021.

[22] M. N. Awang, Z. Zali, N. A. M. Noor, and R. S. Nursal, "Main Propulsion Marine Diesel Engine Condition Based Maintenance Monitoring Using Ultrasound Signal," in Advancement in Emerging Technologies and Engineering Applications, Springer, 2020, pp. 175187.

[23] A. Murty, M. Satyanarayana, and I. Devi, "Compressor Health Monitoring using IOT," Int. J. Mech. Prod. Eng. Res. Dev., vol. 8, no. 3, pp. 117-124, 2019.

[24] A. Angius, M. Colledani, and A. Yemane, "Impact of condition based maintenance policies on the service level of multi-stage manufacturing systems," Control Eng. Pract., vol. 76, pp. 65-78, 2018.

[25] E. OliveiraJr and R. T. Geraldi, "Defect Types and Software Inspection Techniques: A Systematic Mapping Study," J. Comput. Sci., vol. 13, no. 10 SE-Review Article, Oct. 2017.

[26] I. Ardiansah, N. Bafdal, E. Suryadi, and A. Bono, "Greenhouse monitoring and automation using arduino: A review on precision farming and Internet of Things (IoT)," Int. J. Adv. Sci. Eng. Inf. Technol., vol. 10, no. 2, pp. 703-709, 2020.

[27] S. W. Prakosa, M. Faisal, Y. Adhitya, J.-S. Leu, M. Köppen, and C. Avian, "Design and Implementation of LoRa Based IoT Scheme for Indonesian Rural Area," Electronics, vol. 10, no. 1, p. 77, 2021.

[28] Z. Muslimin, A. Siswanto, I. C. Gunadin, and M. Anshar, "Real Time Monitoring of Salinity Gradient and Solar Pond Temperatures," in MATEC Web of Conferences, 2020, vol. 331.

[29] M. Frei, C. Deb, R. Stadler, Z. Nagy, and A. Schlueter, "Wireless sensor network for estimating building performance," Autom. Constr., vol. 111, p. 103043, 2020.

[30] H. Burtscher, T. H. Lutz, and A. Mayer, "A new periodic technical inspection for particle emissions of vehicles," Emiss. Control Sci. Technol., vol. 5, no. 3, pp. 279-287, 2019.

[31] J. S. Parra, B. Ospina, E. F. Mejía, M. L. Orozco-Gutierrez, and J. D. Bastidas-Rodríguez, "Microcontroller Based Low Cost and Modular Architecture for Photovoltaic Array Monitoring," in 2018 IEEE International Conference on Environment and Electrical Engineering 
and 2018 IEEE Industrial and Commercial Power Systems Europe (EEEIC/I\&CPS Europe), 2018, pp. 1-6.

[32] E. S. Hadi, M. Iqbal, and A. W. B. Santosa, "Experimental Measurement of Floating Structure Motion Response Based on the Low-Cost Microcontroller in Towing Tank Laboratory," Int. J. Mech. Eng. Technol. (IJMET, vol. 9, no. 10, pp. 614-624, 2018.

[33] R. S. H. Saputra, Y. E. Priharanto, and M. Z. Latif A, "Failure Mode and Effect Analysis (FMEA) Applied for Risk Assessment of Fuel Oil System on Diesel Engine of Fishing Vessel," ARPN J. Eng. Appl. Sci., vol. 13, no. 21, pp. 8414-8420, 2018.

[34] J. Sun, L. Wang, J. Li, F. Li, J. Li, and H. Lu, "Online oil debris monitoring of rotating machinery: A detailed review of more than three decades," Mech. Syst. Signal Process., vol. 149, p. 107341, 2021.

[35] R. R. Das, S. Kakkad, and E. V. Kumar, "Diesel Engine Control and Protection Monitoring using PID Controller," in 2019 Innovations in Power and Advanced Computing Technologies (i-PACT), 2019, vol. 1, pp. 1-6.

[36] G. Khoobbakht, M. Karimi, and K. Kheiralipour, "Effects of biodieselethanol-diesel blends on the performance indicators of a diesel engine: A study by response surface modeling," Appl. Therm. Eng., vol. 148, pp. 1385-1394, 2019

[37] K. L. J. Kan et al., "Electric Waterjet Thruster Vessel DevelopmentConcept, Charger, and Battery Monitoring," in 2020 8th International Conference on Power Electronics Systems and Applications (PESA), 2020, pp. 1-7.

[38] I. Visnjic, A. Neely, and M. Jovanovic, "The path to outcome delivery: Interplay of service market strategy and open business models," Technovation, vol. 72, pp. 46-59, 2018.

[39] Z. Idrees and L. Zheng, "Low cost air pollution monitoring systems: A review of protocols and enabling technologies," J. Ind. Inf. Integr. vol. 17 , p. $100123,2020$.

[40] C. Titouna, F. Naït-Abdesselam, and A. Khokhar, "DODS: A distributed outlier detection scheme for wireless sensor networks," Comput. Networks, vol. 161, pp. 93-101, 2019

[41] G. Loubet, A. Takacs, and D. Dragomirescu, "Implementation of a battery-free wireless sensor for cyber-physical systems dedicated to structural health monitoring applications," IEEE access, vol. 7, pp. 24679-24690, 2019.

[42] A. Noori, P. Mahbub, J. S. Parry, J. Davis, A. Lucieer, and M. Macka, "Portable device for continuous sensing with rapidly pulsed LEDsPart 1: Rapid on-the-fly processing of large data streams using an open source microcontroller with field programmable gate array," Measurement, vol. 146, pp. 749-757, 2019.

[43] R. A. Alfatah, D. S. Al Musyafa, W. T. Adi, and S. W. Astuti, "A Prototype of Track Gauge and Cant Measurement Device for Curved Railroad by Using Microcontroller," in 2nd International Symposium on Transportation Studies in Developing Countries (ISTSDC 2019), 2020, pp. 72-76.

[44] J. Dalle, M. Elfirman, and M. Sufyan, "Microcontroller Based Water Measurement Level Prototype Using Fuzzy Logic Method," TEM J., vol. 9, no. 2, 2020.

[45] R. Liang, Y. Guo, L. Zhao, and Y. Gao, "Real-time monitoring implementation of PV/T façade system based on IoT," J. Build. Eng., vol. 41, p. 102451, 2021.

[46] M. Zouheir, M. Zniber, S. Qudsia, and T.-P. Huynh, "Real-time humidity sensing by integration of copper sulfide nanocomposite with low-cost and wireless Arduino platform," Sensors Actuators A Phys., vol. 319, p. 112541, 2021 .

[47] M. Kheirkhahan et al., "A smartwatch-based framework for real-time and online assessment and mobility monitoring," J. Biomed. Inform., vol. 89, pp. 29-40, 2019.

[48] V. J. Jimenez, N. Bouhmala, and A. H. Gausdal, "Developing a predictive maintenance model for vessel machinery," J. Ocean Eng. Sci., vol. 5, no. 4, pp. 358-386, 2020.

[49] C. Capezza, S. Coleman, A. Lepore, B. Palumbo, and L. Vitiello, "Ship fuel consumption monitoring and fault detection via partial least squares and control charts of navigation data," Transp. Res. Part D Transp. Environ., vol. 67, pp. 375-387, 2019.

[50] C. Kandemir and M. Celik, "A human reliability assessment of marine auxiliary machinery maintenance operations under ship PMS and maintenance 4.0 concepts," Cogn. Technol. Work, pp. 1-15, 2019.

[51] D. Kurniawati, N. Putra, N. Abdullah, I. I. Hakim, and A. Nurrokhmat, "An experimental analysis of diesel fuel produced from HDPE (highdensity polyethylene) waste using thermal and catalytic pyrolysis with passive heat pipe cooling system," Therm. Sci. Eng. Prog., vol. 23, p. 100917, 2021.

[52] X. Zhu, C. Zhong, and J. Zhe, "Lubricating oil conditioning sensors for online machine health monitoring-A review," Tribol. Int., vol. 109 pp. 473-484, 2017.

[53] N. D. S. A. Santos, V. R. Roso, and M. T. C. Faria, "Review of engine journal bearing tribology in start-stop applications," Eng. Fail. Anal., vol. 108 , p. 104344,2020

[54] D. Kazienko and L. Chybowski, "Instantaneous rotational speed algorithm for locating malfunctions in marine diesel engines," Energies, vol. 13, no. 6, p. 1396, 2020.

[55] V. Karthickeyan, "Effect of combustion chamber bowl geometry modification on engine performance, combustion and emission characteristics of biodiesel fuelled diesel engine with its energy and exergy analysis," Energy, vol. 176, pp. 830-852, 2019.

[56] D. W. Sroyer, M. Z. L. Abrori, and S. D. P. Sidhi, "Maintenance of Freshwater Cooler in the Cooling System of Diesel Engine as a Electric Generator Driver in Navigation Ship of Ambon Class I Navigation," AURELIA J., vol. 1, no. 1, pp. 1-11, 2019.

[57] J. Wang, Z. Wang, F. Gu, X. Ma, J. Fei, and Y. Cao, “An Investigation into the Sensor Placement of a Marine Engine Lubrication System for Condition Monitoring," in Advances in Asset Management and Condition Monitoring, Springer, 2020, pp. 573-582.

[58] C. Dere and C. Deniz, "Effect analysis on energy efficiency enhancement of controlled cylinder liner temperatures in marine diesel engines with model based approach," Energy Convers. Manag., vol. 220 , p. 113015,2020

[59] S. Wang, C. Liu, and Y. Zhou, "Study on Waste Heat Utilization Device of High-Temperature Freshwater in the Modern Marine Diesel Engine," in IOP Conference Series: Earth and Environmental Science, 2018, vol. 111, no. 1, p. 12009.

[60] I. Gritsuk et al., "Improving the Processes of Thermal Preparation of an Automobile Engine with Petrol and Gas Supply Systems (Vehicle Engine with Petrol and LPG Supplying Systems)," SAE Technical Paper, 2020.

[61] V. Abbasi and V. S. Tabar, "Measurement and evaluation of produced energy by thermoelectric generator in vehicle," Measurement, vol. 149, p. $107035,2020$.

[62] Maximintegrated, "DS18B20 Programmable Resolution 1-Wire Digital Thermometer DS18B20 Programmable Resolution 1-Wire Digital Thermometer Absolute Maximum Ratings," vol. 92. pp. 1-20, 2019.

[63] A. O. Okpare, F. I. Anyasi, and D. Ebegba, "Design and Implementation of a Wireless Sensor Network for Monitoring Oil Pipeline," Curr. J. Appl. Sci. Technol., pp. 1-13, 2019.

[64] D. Darjat, S. Sulistyo, A. Triwiyatno, S. Sumardi, and I. Widiyantoro, "Experimental Set-up Design of SOFC Single Cell Performance Using Simple Furnace with Maximum Temperature of 1000 Degrees," Eastern-European J. Enterp. Technol., vol. 1, no. 2, pp. 68-76, 2020.

[65] S. J. M. Algayyim, A. P. Wandel, T. Yusaf, S. Al-Lwayzy, and I. Hamawand, "Impact of butanol-acetone mixture as a fuel additive on diesel engine performance and emissions," Fuel, vol. 227, pp. 118126, 2018.

[66] A. Zare et al., "Emissions and performance with diesel and waste lubricating oil: A fundamental study into cold start operation with a special focus on particle number size distribution," Energy Convers. Manag., vol. 209, p. 112604, 2020.

[67] Y. Septiana, A. R. S. Munthe, D. D. S. Fatimah, and A. Latifah, "Prototype of decision support system for wind detection based on optocoupler and magnetic sensor," in Journal of Physics: Conference Series, 2019, vol. 1402, no. 7, p. 77005.

[68] G. Gabiña, L. Martin, O. C. Basurko, M. Clemente, S. Aldekoa, and Z. Uriondo, "Performance of marine diesel engine in propulsion mode with a waste oil-based alternative fuel," Fuel, vol. 235, pp. 259-268, 2019.

[69] R. Islam, M. Anantharaman, F. Khan, and V. Garaniya, "Reliability assessment of a main propulsion engine fuel oil system-what are the failure-prone components?," TransNav Int. J. Mar. Navig. Saf. Sea Transp., vol. 13, no. 2, 2019.

[70] R. Yarinezhad and S. N. Hashemi, "Increasing the lifetime of sensor networks by a data dissemination model based on a new approximation algorithm," Ad Hoc Networks, vol. 100, p. 102084, 2020.

[71] J. Poppe, R. N. Boute, and M. R. Lambrecht, "A hybrid conditionbased maintenance policy for continuously monitored components with two degradation thresholds," Eur. J. Oper. Res., vol. 268, no. 2, pp. 515-532, 2018.

[72] X. Jin and G. Zhang, "Design and Realization of the electronic clock with E Ink screen," in 2020 IEEE 4th Information Technology, Networking, Electronic and Automation Control Conference (ITNEC), 2020, vol. 1, pp. 2366-2369. 
[73] H. R. Iskandar, S. Basuki, M. R. Hidayat, A. D. Setiawan, D. Rukanda, and S. U. Prini, "Wireless Telemetry for Real-time Monitoring of Photovoltaic Application System using Monopole Antenna 3DRobotics Radio $915 \mathrm{MHz}$," in 2019 IEEE 13th International Conference on Telecommunication Systems, Services, and Applications (TSSA), 2019, pp. 277-281.

[74] M. D. Mudaliar and N. Sivakumar, "IoT based real time energy monitoring system using Raspberry Pi," Internet of Things, vol. 12, p. 100292,2020

[75] Z. Mumtaz, Z. Ilyas, A. Sohaib, S. Ullah, and H. A. Madni, "Design and Implementation of User-Friendly and Low-Cost MultipleApplication System for Smart City Using Microcontrollers," arXiv Prepr. arXiv2010.07016, 2020.

[76] A. D. Wickert, C. T. Sandell, B. Schulz, and G.-H. C. Ng, "Opensource Arduino-compatible data loggers designed for field research.," Hydrol. Earth Syst. Sci., vol. 23, no. 4, 2019.

[77] M. D. Khairunnas, E. Ariyanto, and S. Prabowo, "Design and implementation of smart bath water heater using arduino," in 2018 6th International Conference on Information and Communication Technology (ICoICT), 2018, pp. 184-188.

[78] I. T. F. de Resende et al., "Use of a solar low-cost open-source controlled plant for WCOEE synthesis based on eggshell catalyst," Bioresour. Technol. Reports, vol. 11, p. 100430, 2020.

[79] D. L. Zariatin, D. Rahmalina, E. Prasetyo, A. Suwandi, and M. Sumardi, "The effect of surface roughness of the impeller to the performance of pump as turbine pico power plant," J. Mech. Eng. Sci., vol. 13, no. 1, pp. 4693-4703, 2019.

[80] P. Sudira and R. E. Juwanto, "Design training kits CPI for vocational learning in industry 4.0," Int. J. Recent Technol. Eng., 2019.

[81] F. K. Pala and P. Mıhçı Türker, "The effects of different programming trainings on the computational thinking skills," Interact. Learn. Environ., 2019

[82] K. Xu, Q. Chen, Y. Zhao, C. Ge, S. Lin, and J. Liao, "Cost-effective, wireless, and portable smartphone-based electrochemical system for on-site monitoring and spatial mapping of the nitrite contamination in water," Sensors Actuators B Chem., vol. 319, p. 128221, 2020.

[83] P. Visconti, R. de Fazio, P. Costantini, S. Miccoli, and D. Cafagna, "Arduino-Based Solution for In-CarAbandoned Infants' Controlling Remotely Managed by Smartphone Application," J. Commun. Softw. Syst., vol. 15, no. 2, pp. 89-100, 2019.

[84] M. Krishnamoorthi and R. Malayalamurthi, "Experimental investigation on performance, emission behavior and exergy analysis of a variable compression ratio engine fueled with diesel-aegle marmelos oil-diethyl ether blends," Energy, vol. 128, pp. 312-328, 2017

[85] S. Neumann, R. A. Varbanets, and O. I. Kyrylash, "Marine diesels working cycle monitoring on the base of IMES GmbH pressure sensors data," Техническая эксплуатачия водного транспорта проблемы и пути развития, по. 1-1, 2019

[86] I. Ahmad, M. F. Suhaimi, and N. A. N. Yusri, "Development of alcohol sensor detector with engine locking system for accident prevention," in AIP Conference Proceedings, 2019, vol. 2129, no. 1, p. 20196.

[87] E. Murdyantoro, A. W. W. Nugraha, A. W. Wardhana, A. Fadli, and M. I. Zulfa, "A review of LoRa technology and its potential use for rural development in Indonesia," in AIP Conference Proceedings, 2019, vol. 2094, no. 1, p. 20011

[88] L. Zhang, Y.-C. Liang, and M. Xiao, "Spectrum sharing for Internet of Things: A survey," IEEE Wirel. Commun., vol. 26, no. 3, pp. 132-139, 2018.

[89] Y. Li and J. He, "Design of indoor environment monitoring system based on WiFi," in 2018 2nd IEEE Advanced Information Management, Communicates, Electronic and Automation Control Conference (IMCEC), 2018, pp. 1-1845.

[90] B. Yamamoto et al., "Received signal strength indication (RSSI) of 2.4 $\mathrm{GHz}$ and $5 \mathrm{GHz}$ wireless local area network systems projected over land and sea for near-shore maritime robot operations," J. Mar. Sci. Eng., vol. 7, no. 9, p. 290, 2019.

[91] A. Stetco et al., "Machine learning methods for wind turbine condition monitoring: A review," Renew. energy, vol. 133, pp. 620-635, 2019.

[92] R. Senthilkumar, P. Venkatakrishnan, and N. Balaji, "Intelligent based novel embedded system based IoT enabled air pollution monitoring system," Microprocess. Microsyst., vol. 77, p. 103172, 2020.

[93] G. A. Francis, M. Dhinesh, J. A. Lijo, P. Hariprasad, and K. Balasubramanian, "IoT Based Vehicle Emission Monitoring System," Int. J. Innov. Technol. Explor. Eng., vol. 8, pp. 410-412, 2019.

[94] R. Firmansyah, M. Yusuf, P. P. S. Saputra, M. E. Prasetyo, F. M. Mochtar, and F. A. Kurniawan, "IoT Based Temperature Control System Using Node MCU ESP 8266," in International Joint Conference on Science and Engineering (IJCSE 2020), 2020, pp. 401407.

[95] H. R. Choi, Y. S. Moon, J. J. Kim, J. K. Lee, K. B. Lee, and J. J. Shin, "Development of an IoT-based container tracking system for China's Belt and Road (B\&R) initiative," Marit. Policy Manag., vol. 45, no. 3, pp. 388-402, Apr. 2018

[96] A. P. Montoya, F. A. Obando, J. A. Osorio, J. G. Morales, and M. Kacira, "Design and implementation of a low-cost sensor network to monitor environmental and agronomic variables in a plant factory," Comput. Electron. Agric., vol. 178, p. 105758, 2020.

[97] A. Martín-Garín, J. A. Millán-García, A. Baïri, J. Millán-Medel, and J. M. Sala-Lizarraga, "Environmental monitoring system based on an Open Source Platform and the Internet of Things for a building energy retrofit," Autom. Constr., vol. 87, pp. 201-214, 2018

[98] K. M. Ramadan, M. J. Oates, J. M. Molina-Martinez, and A. RuizCanales, "Design and implementation of a low cost photovoltaic soil moisture monitoring station for irrigation scheduling with different frequency domain analysis probe structures," Comput. Electron. Agric., vol. 148, pp. 148-159, 2018.

[99] N. Sugiartha, I. M. Sugina, I. D. G. A. T. Putra, M. A. Indraswara, and L. I. D. Suryani, "Development of an Arduino-based Data Acquisition Device for Monitoring Solar PV System Parameters," in International Conference on Science and Technology (ICST 2018), 2018.

[100] N. A. Hidayatullah et al., "Volcano multiparameter monitoring system based on Internet of Things (IoT)," Aust. J. Electr. Electron. Eng., vol. 17 , no. 3, pp. 228-238, 2020.

[101] S. Zhang and Z. Zhang, "Research on the field dynamic balance technologies for large diesel engine crankshaft system," Shock Vib., vol. $2017,2017$.

[102] M. Nazoktabar, K. Arshtabar, and H. Mohammadkhani, "Investigating the effect of coolant's heat transfer type on thermostat placement," $J$. Therm. Anal. Calorim., vol. 139, no. 4, pp. 2519-2526, 2020.

[103] L. Özgür, V. K. Akram, M. Challenger, and O. Dağdeviren, “An IoT based smart thermostat," in 2018 5th International Conference on Electrical and Electronic Engineering (ICEEE), 2018, pp. 252-256.

[104] T. Alves, M. C. D'Carvalho, and R. S. Gonçalves, "Assist-as-needed control in a cable-actuated robot for human joints rehabilitation," J Mech Eng Biomech, vol. 3, pp. 57-62, 2019.

[105] W. Hlaing, S. Thepphaeng, V. Nontaboot, N. Tangsunantham, T. Sangsuwan, and C. Pira, "Implementation of WiFi-based single phase smart meter for Internet of Things (IoT)," in 2017 International Electrical Engineering Congress (iEECON), 2017, pp. 1-4.

[106] H. S. Munawar, S. Qayyum, F. Ullah, and S. Sepasgozar, "Big Data and Its Applications in Smart Real Estate and the Disaster Management Life Cycle: A Systematic Analysis,” Big Data Cogn. Comput., vol. 4, no. 2, p. 4, 2020.

[107] M. Saez, F. P. Maturana, K. Barton, and D. M. Tilbury, "Real-time manufacturing machine and system performance monitoring using internet of things," IEEE Trans. Autom. Sci. Eng., vol. 15, no. 4, pp $1735-1748,2018$

[108] A. Halim et al., "Developing a functional definition of small-scale fisheries in support of marine capture fisheries management in Indonesia," Mar. Policy, vol. 100, pp. 238-248, 2019.

[109] S. Pradeep and Y. K. Sharma, "Storing Live Sensor Data to the Platforms of Internet of Things (IoT) Using Arduino and Associated Microchips," in Proceedings of the Third International Conference on Computational Intelligence and Informatics, 2020, pp. 1-15.

[110] S. Jiang, "Marine Internet for Internetworking in oceans: A tutorial," Futur. Internet, vol. 11, no. 7, p. 146, 2019.

[111] D. F. Hariyanto, I. J. M. Edward, and T. Juhana, "Marine Radio for Voice Communication System on Very High Frequency (VHF) Spectrum," in 2019 IEEE 5th International Conference on Wireless and Telematics (ICWT), 2019, pp. 1-6. 